\title{
CONCEPT AND CLASSIFICATION OF DERIVATIVE FINANCIAL INSTRUMENTS AS A METHODOLOGICAL PRECISION ON THEIR REGULATION IN THE FINANCIAL SERVICES MARKET
}

\author{
Oksana Novak' ${ }^{1}$ Tetiana Osadcha ${ }^{2}$, Oleksandr Petruk ${ }^{3}$
}

\begin{abstract}
The urgency of the research topic is caused by the rapid growth of capital markets and the emergence of all new financial instruments, the complexity of their structure and the transition beyond the regulatory influence of supervisory authorities. Discussion issues on the identification of derivatives, as well as their certain types, create significant problems with their valuation, the correctness of accounting, and the application of regulatory measures. Inconsistency in the interpretation of derivative financial instruments nature and their certain types is also present in domestic legal acts. Therefore, until the elimination of these shortcomings, derivative financial instruments create additional risks for their owners - financial institutions, as well as for creditors and depositors. The purpose of the research, conducted in the article, lies in the clarification of derivatives nature and developing an appropriate classification of their types in order to its further use with a view of regulation. The methodological basis of the research. The methodological basis of the study is a dialectical approach to the understanding of the essence of derivative financial instruments; general scientific methods of knowledge of phenomena and processes (monographic, abstract-logical, synthesis, comparison, generalization), analysis of legal acts in the part of treatment of derivatives, derivative financial instruments and derivative securities, methods of grouping systematization and generalization in developing the classification of derivative financial instruments. Scientific results. It has been established that in order to maintain the stability of financial markets and their participants, the transformation of regulatory measures should be a permanent development and modification of the financial instruments that are being rotated. Various approaches to the interpretation of derivative financial instruments essence in normative legal acts and scientific literature have been analysed in order to improve the regulation of their issuance and circulation. This made it possible to streamline the conceptual apparatus and to group certain types of derivatives according to certain classification grounds. The basis for classification is the concept of "derivative financial instruments" as the broadest, which includes derivative securities and term contracts (derivatives). The concept of derivatives and derivative securities are delimited based on the study of terminology. It was established that derivatives are standard documents that certify the right and/or obligation to purchase or sell future securities, tangible or intangible assets, as well as funds or make payments on terms and conditions specified by them. However, in some cases, derivatives may acquire features of derivative securities, in particular, when issued through emission and freely traded in markets and bring income (losses) to their owner as a result of changes in their market value. The practical significance. The practical value of the research is the possibility of using the developed classification for the needs of emission regulation and the circulation of derivative financial instruments.
\end{abstract}

Key words: derivative financial instruments, derivative securities, term contracts, asset securitization instruments, hybrid securities, classification of derivative financial instruments.

JEL Classification: G01, G14, G28

\footnotetext{
Corresponding author:

${ }^{1}$ Zhytomyr State Technological University, Ukraine.

E-mail: novak_os@ukr.net

ORCID: https://orcid.org/0000-0002-5671-0306

${ }^{2}$ Kherson State University, Ukraine.

E-mail: tatiana@osadcha.com

ORCID: https://orcid.org/0000-0003-4258-0907

${ }^{3}$ Zhytomyr State Technological University, Ukraine.

E-mail: petruk6@gmail.com

ORCID: https://orcid.org/0000-0002-5351-5679
} 


\section{Introduction}

Integration and globalization processes contribute to the rapid inclusion of financial institutions in the global financial space. Opportunities for access to foreign capital markets, on the one hand, open the broad preconditions for the growth of profitability, but on the other hand, they limit the possibility of the regulatory influence of the state and, therefore, create additional threats. Financial institutions do not always work in the interests of clients or national interests. First and foremost, their policy is aimed at protecting their own economic interests by attracting cheaper sources of funding and increasing profitability, including the use of the latest financial technologies: the securitization of assets, conclusion of fixed-term contracts, and use of other derivative financial instruments. At the same time, unlimited growth of the secondary stock market and the number of potentially defaulting financial instruments threatens not only their direct holders and issuers financial institutions but also their clients. Therefore, the issue of regulating the issuance and circulation of derivative financial instruments in the financial services market becomes particularly relevant in the post-crisis period. The use of adequate regulatory measures at the national level needs to streamline both - the conceptual apparatus of derivative financial instruments and the systematization, and further classification of their types in order to identify their potential risks as for the issuer, as for the investor. Therefore, the purpose of the article is to study the essence of derivative financial instruments and to develop a classification of their types for the purpose of its further use for regulatory purposes. In order to achieve this goal, it is necessary to review the scientific literature on the issues of regulation of derivative financial instruments, to study approaches to the essence interpretation of the derivative financial instruments in legal acts and scientific works, to identify the characteristic features of derivative securities and term contracts, and to determine their place in classification of derivative financial instruments. The methodological basis of the study is a dialectical approach to the understanding of the essence of derivative financial instruments; general scientific methods of knowledge (monographic, abstract-logical, synthesis, comparison, generalization), analysis of legal acts in the part of treatment of derivatives, derivative financial instruments and derivative securities, methods of grouping systematization and generalization in developing the classification of derivative financial instruments.

\section{Literature review}

Since derivative financial instruments have become widespread in financial markets relatively recently, and continue to grow and become more complicated, most of the works of both foreign and domestic scholars are mainly concerned with their essence and circulation. In particular, varieties of derivative financial instruments were considered in their writings by F. J. Fabozzi (Fabozzi, 2007), Jan Job de Vries Robbe and Paul U Ali (Jan Job de Vries Robbe, Ali Paul, 2008), A. B. Feldman (Feldman, 2003), Joseph Sinkey (Sinkey, 2007), H. P. Bär (Bär, Hans Peter, 2006), L. Prymostka (Prymostka, 2001), S. Z. Moshenskyi (Moshenskyi, 2018), O. V. Dziubliuk (Dziubliuk, 2009), L. V. Kuznetsova (Kuznetsova, Abramova, 2016) and others. At the same time, the conceptual framework for regulating the issue and circulation of derivative financial instruments in the financial services market has not yet been developed. The root causes of the lack of thorough research on the above issues are the lack of common approaches to the interpretation of derivative financial instruments and the systematization of their types. In addition, it should be noted that one of the main ideas for the creation of most derivative financial instruments (especially credit) was the desire of financial institutions to circumvent the requirements of legislation on the minimum size of capital.

In the work "Securitization and Law" (written before the financial crisis of 2008), the authors deal with certain aspects of banking regulation, however, regulating nonissuance processes and the circulation of securitization and credit derivative instruments, and their use to avoid the requirements of the Basel Committee regarding capital adequacy. In particular, researchers note that the build-up of equity or the formation of reserves for credit operations leads to a decline in the profitability of a commercial bank. Prior to the adoption of the Basel Accords, the strengthening of regulatory measures by the states on domestic markets led to the outflow of capital in countries, where there were milder capital adequacy requirements (Jan Job de Vries Robbe, Ali Paul, 2008). In current conditions, when most countries backed the Basel Accord on capital adequacy, the chaotic capital outflow was stopped, but financial institutions began to develop other methods that would allow circumventing restrictions and raising profitability. These methods are presented in the financial markets by instruments of classical and synthetic securitization, as well as by credit derivatives that enable to write off long-term assets with high risks or transfer risk assets to other market entities, which reduces reserves and increase profitability by investing funds released into new loans.

However, Jan Job de Vries Robbe and Ali Paul in their book stressed that "derivatives, as risk insurance instruments, are also the source of new risks in the operations in the global financial market. The main trouble of derivatives is that their operations, by allowing the use of relatively small amounts of liquid assets, generate not just a great income, but losses (leverage) as well (Jan Job de Vries Robbe, Ali Paul, 2008). For example, the authors show the bankruptcy in 1995 of the investment Barings Bank, whose history extends back 233 years of activity. The reason for bankruptcy was that 
a trader of Singaporean bank branch Nick Leeson lost in a very short time in the futures and options contracts on the index "Nikkei 225" 1,3 billion dollars (Jan Job de Vries Robbe, Ali Paul, 2008).

Considering the issue of regulating the treatment of derivatives and other derivative financial instruments, J. Sinkey Jr., even mentioning about the bankruptcy of Barings Bank, notes that both buyers and sellers of derivatives should use mechanisms for adequate internal control. The researcher draws attention to the fact that since "most derivative transactions are 'zerosum games', the crises of 1994 and 1995 did not require government intervention or regulators. Internal control and external market monitoring in such cases are better than interference by regulators," - sums up the author (Sinkey, 2007).

However, the financial crisis of the 2008 year showed all the disadvantages of overly liberal approaches in regulating speculative transactions with derivative financial instruments. In the monograph "Chaos and Synergy. The Securities Market of the Post-Industrial Era” S. Z. Moshenskyi describes in detail the crisis of 2007-2009 and the bankruptcy of the largest financial institutions that went bankrupt mainly because of derivative financial instruments. In particular, the author mentions the unprecedented case of the allocation of financial assistance from FRS to the investment bank Bear Stearns, one of the major participants in the market of credit default swaps, issued for "toxic" assets that have been burdening the balance sheets of other banks. Subsequently, with the assistance of the FRS, the financial conglomerate Bank of America absorbed the virtually bankrupt Merrill Lynch investment bank (the reason for financial turmoil was the excessive emission of CDOs that fell in price). When banks formed troubled loan assets, it was unprofitable to take them into account on the balance sheet, as it is necessary to create additional reserves in order to maintain the permissible ratio of equity and risk assets. Therefore, banks did not take into account portfolios of mortgage loans on their own balance sheets but transferred to the balance sheets of their non-banking structured investment vehicles (SIV), which were not subject to bank capital requirements. In such companies, mortgage bonds were also kept for very large sums, which banks united in a pool with the emission of CDO. However, full SIV revenue was then transferred to banks (Moshenskyi, 2018).

The first in the US history was also the case of nationalization of the life insurance company AIG, whose leadership until the collapse of the real estate market has opened a long position in credit default swaps by 50 billion of the US dollars; the total amount of loans provided by the US government to AIG amounted up to 223 billion of the US dollars (Moshenskyi, 2018).

The crisis of 2007-2009 has caused a number of defaults not only in the USA but also in countries of Europe and Asia, as financial institutions in search of high incomes willingly invest in high-risk but undervalued derivative financial instruments: $\mathrm{CDO}$ and CDS.

Some scholars even nowadays adhere to the principles of liberalizing financial markets, as the cause of the crisis is seen in over-the-counter derivative financial instruments. In particular, the problem of managing the risks of trading in derivative financial instruments is considered in his work by Peter Norman. In his study, the author analyses the bankruptcy of major financial institutions in 2008 and recognizes the high risks of OTC credit derivatives that caused them. However, P. Norman considers sufficient measures to prevent further crises - the transfer of OTC trading in credit derivatives clearing the participation of central counterparties (acting buyers to sellers and sellers to buyers at the specific agreement and can ensure closing position traders formed reserves) and standardization of most forms of credit derivatives (Norman, 2013). However, as shown, even partial closing of open positions in risky derivatives central counterparties not warned of large-scale defaults, and could not be, because the size of the reserves for the open position is often at a minimum $-10 \%$ of the potential deal.

Is there the threat of a global financial crisis today? Obviously, there is such a threat because, although, the volumes of derivative financial instruments stopped their rapid growth, nevertheless, the tendency of growth and approximation of their volumes to precrisis indicators remains. In addition, statistics show the imbalance of commodity and financial markets. In particular, the volume of gross world product is 123 trillion of the US dollars (Poodwaddle world clock, 2018) and the volumes of global market capitalization of derivatives (excluding traditional securities and structured securities) as of October 2017 amounted to about 544 trillion, which is 4 times more than the amount of assets, for which they are issued (Desjardins Jeff, 2017). In addition, in recent years, new financial asset markets have emerged, namely, the crypt market with high levels of volatility. And already in December 2017, the Chicago Stock Exchange opened its first futures trading on the bitcoin - one of the most risky derivative financial instruments.

In our opinion, taking into account the peculiarities of the domestic financial system, it is inappropriate and risky to adhere to overly liberal approaches to regulating transactions of financial institutions in the derivative financial instruments markets. In particular, the domestic banking system differs from the American type, namely, there are no investment banks in Ukraine in the traditional sense and, based on the current legislation, all commercial banks have the right to raise funds on deposit accounts, and therefore, carrying out risky investments or other operations, they mainly take a risk of losing attracted funds. In addition, a funded pension system is being created in Ukraine, which will give impetus to significant revenues from public funds 
to non-state pension funds and investment funds that, in search of high incomes, may resort to risky investments. In such circumstances, it is necessary to develop national approaches to regulating transactions of financial institutions with derivative financial instruments. At this stage, there are clear tasks: first, to determine the essence of derivative financial instruments (even in the legislation, there are no common approaches to interpretation and classification); and secondly, to develop a classification of derivative financial instruments, which will enable them to be grouped at risk level and further define approaches to their assessment and application of regulatory measures.

\section{Analysis of the regulatory framework for the interpretation of the essence of derivative financial instruments}

Nowadays, there is no single approach to the interpretation of the concept of "derivative financial instruments" in the economic literature. Quite often, this concept is identified with the notions of "derivative securities", "secondary securities", "derivatives", "hybrid financial instruments", and "hybrid securities". Thus, in the literature, the discussion on the definition of these concepts is still ongoing, as specific types of complex financial instruments undergo new modifications and acquire properties that are not characteristic of such instruments in their previous version. Such modifications of financial instruments allow them to go beyond the legal regulation and regulatory influence of supervisory financial authorities. At the same time, the interchange of concepts leads to the practical problems of identifying a particular derivative financial instrument, the order of its assessment and reflection in the accounting system, as well as the order of formation of appropriate reserves to cover risks for it.

Since the international community seeks to unify the accounting and reporting system, and Ukraine is actively involved in this process, it is advisable to consider the interpretation of conceptual concepts in IAS and IFRS. The key concept in international standards is the notion of "financial instrument", which means "...any contract that results in a financial asset from one entity and a financial liability or equity instrument from another entity" (Verkhovna rada Ukrajiny, IAS 32, 2012). Based on the essence of the concept, it includes term contracts (derivatives), as well as traditional securities, since both of them lead to the emergence of a financial asset of one entity and financial liability of another one.

IFRS 9 Financial Instruments defines the term "derivative", which is defined as "...a financial instrument or another contract within the scope of this Standard, which has all three of the following characteristics: a) its value varies in response to changes in a specific interest rate, financial instrument price, commodity price, exchange rate, price or interest rate index, credit rating or credibility index, or another variable, provided that in the case of a non-financial variable, this variable is not specific to a to the contracting party (sometimes called the base one); b) which does not require initial net investment or initial net investment less, than what would be required for other types of contracts that are expected to have a similar response to changes in market factors; c) to be repaid on a future date" (Verkhovna rada Ukrajiny, IFRS 9, 2012).

It should also be noted, that there are no definitions of "derivative securities", "hybrid securities" and "fixed-term contracts" in the International Accounting Standards and Financial Reporting Standards.

So, for further differentiation between the concepts of "derivative financial instruments", "derivative securities" and "derivatives", we will analyse the norms of domestic legislation, regarding the interpretation of the above concepts.

The Law of Ukraine "On Securities and the Stock Market" defines several key concepts that allow distinguishing between financial instruments, securities, and derivative securities.

In particular, financial instruments in the Law "On Securities and the Stock Market" are interpreted as "...securities, term contracts (futures), interest rate contracts (forwarders), term contracts for exchange (for a certain date in the future) in case of prices dependence from the interest rate, the exchange rate or the stock index (interest, exchange rate or index swaps), options that give the right to purchase or sell any of these financial instruments, including those that provide monetary form of payment (exchange rate and interest options)" (Vidomosti Verkhovnoji Rady Ukrajiny, 2006). So, domestic legislation gives a list of financial instruments, which include both securities and term contracts. However, a security is perceived as "a document established form with relevant details that certifies monetary or other proprietary right, defines the relationship between the issuer of securities (the person, who issued the security) and the person, who has the right to security, and provides performance obligations related to such securities and the possibility of transferring rights for security for other individuals" (Vidomosti Verkhovnoji Rady Ukrajiny, 2006). Thus, securities in Ukraine may include those financial instruments that are issued on the basis of emission, certify monetary or other property rights. It means that such a derivative financial instrument, as a forward contract, cannot be a security.

In addition, the law also treats the concept of "derivative securities", which refers to securities, whose issue and circulation mechanisms are related to the right to purchase or sell securities, other financial and/ or commodity resources within the term established by the agreement (Vidomosti Verkhovnoji Rady Ukrajiny, 2006). The Law of Ukraine "On Securities and the Stock Market" does not define the term "derivative" 
but this term is defined in the Tax Code of Ukraine and is interpreted as: "...standard document, certifying the right and/or obligation to purchase or sell future securities, tangible or intangible assets, as well as funds on the terms specified by it. The procedure for issuance and circulation of derivatives is established by law. The standard (typical) form of derivatives is approved by the Cabinet of Ministers of Ukraine" (Vidomosti Verkhovnoji Rady Ukrajiny, 2010).

Derivatives, in accordance with the Tax Code of Ukraine, include: swap, option, forward contract and futures contract. At the same time, the determining factor is the fact, that there are no identifying derivatives with security in the definitions. In particular, the swap is defined as a "civil agreement..."; the option is treated as a "civil-law agreement..."; forward contract - as "standardized civil contract...", and a futures contract (futures) - as a "standardized term contract..." (Vidomosti Verkhovnoji Rady Ukrajiny, 2010). The analysed approaches to the interpretation of "derivative financial instruments", "derivative securities" and "derivatives" indicate, on the one hand, the inconsistency of the interpretations in various legal acts and the lack of a common approach, and on the other hand, the significant differences between derivatives and securities, which do not allow them to be equated.

\section{Disclosure of concept of derivative financial instruments in scientific literature}

If we analyse the reference literature, then the Great Dictionary of Modern Ukrainian determines the "derivative" as "...created, derived, etc. from another similar (size, form, category, etc.).” In this case, derivative securities are treated as "...securities, whose release mechanism is linked to the right to purchase or sell financial and/or commodity resources" (Busel, 2005).

The etymology of the term "derivatives" was explored by Feldman, who points out that the term "derivatives" originates from Latin origin word "derivatus" and means "a derivative, created from something existing earlier." The derivative is based on the movement (time change) of the level (profitability) and the mass of income (profit, margin) for current and future cash flows, directly or indirectly dependent on the movement (change) of income or other types, kinds, methods of cash investments (cash flows). There are hidden links in these dependencies, which are determined by a large number of circumstances (objective and exogenous, subjective and endogenous) in relation to financial markets. Under the direct or indirect dependence, it is necessary to understand the features of the realization of the derivation (with a basis in the form of a trade item, in the form of an abstract calculated value based on the price of the underlying asset, etc.). In this case, the scientist includes futures, options, swaps, as well as their combinations that realize the synergistic effect, to derivatives of financial products-tools (financial contracts) (Feldman, 2003).

O. O. Kvaktun identifies the concept of "derivatives" and "derivative securities". In particular, the scientist states that: "...the derivative should be considered, first of all, as a contract for a term, an agreement between two persons, which has (or may) be fulfilled in the future. Derivatives are precisely derivative securities because, being the assets themselves, they fix an agreement on other assets. There is no derivative without a reference asset. The issuance of derivatives is always secondary to the basic asset, lying in their basis" (Kvaktun, 2014).

A. N. Burenin adheres to an opposite approach to the derivatives' interpretation. The scientist introduces the concept of "term contract", which he understands as an agreement on the future supply of the contract subject (Burenin, 1998). At the same time, the author specifies that term contracts have another title, namely, "derivative assets" but argues that derivative assets (fixed-term contracts) and derivative securities perform different functions, and therefore, they are not identical concepts. The author substantiates his opinion as follows: "First, the valuable paper is the title of the property for certain property or debt capital. A term contract is only the right or obligation to put or buy in the future base asset. It serves as an organizational delivery tool. Secondly, the main function of the stock market is to mobilize cash. The function of the term market is to hedge the price risks and to agree on future business plans. Thirdly, securities typically generate income in the form of dividends or interest; there are no such types of income on fixed-term contracts" (Burenin, 1998).

Researchers V. Sheludko and V. Virchenko consider derivatives of the international market, which include futures, options, forwards, swaps, agreements on forward interest rates, etc. They coincide with the same instruments that are in circulation on national markets, by title and content, but their issue and circulation is not a subject to the regulation of any country but is regulated by agreements, instructions, contracts, and other documents, existing in the international market (Sheludjko, Virchenko, 2014). Thus, academics combine futures, options, forwards, swaps, forward interest rate agreements, and others under the generic term "derivative financial instruments."

Belarusian scientists L. M. Rikova and P. V. Viktorovich considered the necessity of regulating the derivative market. Researchers emphasize that the volume of derivatives in 10 times exceeded world GDP in 2008, and in the daily volume of foreign exchange operations in the world foreign exchange market ( 2 trillion USD) only $5-7 \%$ of this amount is related to the real economy, another part - to speculative dealings, which necessitates a clear understanding of the concept "derivatives" and the development of effective mechanisms of influence on their number. The researchers point out that the primary purpose of derivatives is to minimize risks, and 
the derivative itself is a derivative instrument in the form of a financial contract, the price of which depends on the price of the assets, laid down on its basis or financial indicators (futures, swaps, options, forwarders, and others) (Rykova, Viktorovich, 2009).

In addition, researchers attribute the classification of derivatives to the degree of derivativeness of the traditional asset: first-order financial derivatives, second-order financial derivatives, and third-order financial derivatives. First-order financial derivatives include bonds derived from loans, that is, MBS (Mortgage-Backed Securities, bonds secured by mortgages) and ABS (Asset-Backed Securities, bonds provided with other assets). Second-order financial derivatives include CDO (Collateralized Debt Obligation, actual derivatives of first-order derivatives). CDO is a debt secured bond and is derived from $\mathrm{MBS}$ and $\mathrm{ABS}$. The basis of $\mathrm{MBS}$ and $\mathrm{ABS}$ is the payment of the corresponding loans, and CDO - payments for MBS and ABS. Thirdorder derivatives are represented by the $\mathrm{CDO}$, based on the cash flows of other CDOs, that is, the CDO can be the third, fourth, and subsequent orders. As a conclusion, the researchers point out that in general such operations are called securitization of banking assets through the transformation of the loan portfolio in traded securities (derivatives) (Rykova, Viktorovich, 2009).

Thus, this approach identifies derivative financial instruments, derivatives, and asset securitization instruments. However, it has a significant disadvantage: the classification of derivatives by the degree of derivation from the traditional asset does not include traditional term contracts: futures, swaps, options, forwards, which the researchers also attributed to derivatives, but have not included to the classification. That is, traditional term contracts have not been reflected in the classification of derivatives by the degree of derivation from a traditional asset since they have a slightly different nature, different from asset securitization instruments, and therefore, they cannot be identified.

On this occasion, T. V. Makshanova and O. G. Kovalenko note that any security is a financial instrument, but not every financial instrument is security (Makshanova, Kovalenko, 2013). In addition to this opinion, it should be noted that the concept of "financial instrument" is broader in its content compared with the concept of "security" and includes the last one, therefore, quite often in the economic literature these concepts are used as synonyms. However, for derivative financial instruments and derivatives, there must be clear separation, including futures, forward, option and swap contracts - these are derivative financial instruments, and futures, forward, option and swap, traded on the market, as a separate asset, are derivative securities.

Moreover, researchers raise an important issue related to the separation or identification of the concepts of "derivative securities" and "secondary securities". Based on the interpretation of the concepts of "derivative" and "secondary", the researchers argue that the concept of "derivative securities" and "secondary securities" are synonyms and include convertible bonds, warrants, depositary receipts, certificates of shares (Makshanova, Kovalenko, 2013).

In the economic literature, there are also views that identify derivatives and derivative financial instruments: "derivative financial instruments are called derivatives. These include the following transactions: currency swap, credit default swap, option, futures, etc." (Loginov, Loginova, 2012) Scientists also explain that financial agreements are called derivatives because their conditions are based on the relevant parameters of another financial instrument, which is a basic one. Thus, the main purpose of acquiring a derivative is not to obtain a base asset but to obtain a profit (income) from a change in its price. In addition, the authors point out that derivatives are defined as fixed-term contracts since their obligations arise at a specific time. Derivatives are the basis of structured financial products (securities) (Loginov, Loginova, 2012).

Tony Rice and Brian Coyle share options, as well as stock and futures contracts, based on stock indexes, refer to derivatives of the capital market instruments. Scientists point out that they are not a source of capital and are not issued by companies but allow investors to manage investment risks by reducing the likelihood of adverse changes in stock prices and also allow speculation on positive changes in prices at relatively low cost. The authors include stock options, stock quotes options, stock-based futures, and index-futures options to derivative financial instruments. In addition, scholars are considering hybrid financial instruments (convertible bonds, bonds with warrants and preferred shares) that mean securities, which have features as of common stock, as of loan instruments at the same time. At the same time, the authors argue that, in the broad sense, hybrid financial instruments include any instrument that combines signs of two or more types of securities (Tony Rice, Brian Coyle, 1995).

Rice's and Coyle's approach to hybrid securities and the feature that theylaid the foundation for their identification is quite successful, but it needs to be substantiated. In particular, the Great Interpretative Dictionary defines the adjective "hybrid" in two aspects: the derivation of hybridization, as well as hybrid securities, is securities in the form of bonds, which can simultaneously be used as preferred cumulative shares. (Busel, 2005). Also, the term "hybridization" is defined in the dictionary - the crossing of different species of animals and plants in order to obtain qualitatively new, better descendants (Busel, 2005). If we depart from the biological aspect of hybridization and translate it into the prism of financial instruments, then it can be interpreted as a combination of different types of securities to obtain a qualitatively new financial instrument (security). Therefore, hybrid securities must be classified, as securities that contain, at the same time, signs of two or more traditional securities. 


\section{Findings}

Based on the results of the analysis, it can be noted that the broad concept among the researchers is the concept of "derivative financial instruments." Sufficiently successful interpretation of "derivative financial instruments", with reference to IFRS 13 Financial Instruments, is given in the glossary of NBU terminology, namely: "derivative financial instruments (derivatives) - financial contracts or financial instruments, based on other financial instruments that are called base instruments. The basis for such a financial instrument (contract) may be assets (for example, goods, stocks, residential collateral, real estate, bonds, loans), indices (interest rates, exchange rates, stock indices, consumer price indices) or other conditions. Credit derivatives originate from loans, bonds or other forms of lending" (Nacionaljnyj bank Ukrajiny, 2018). However, the results of the research do not allow extending the term of derivatives to all types of derivative securities. Therefore, it is necessary to eliminate in the legislation the interchangeability of the terms "derivative financial instruments" and "derivatives" but to include the last notion in the list of financial instruments. In this case, derivatives should be understood, as term contracts in the form of a standard document certifying the right and/or obligation to purchase or sell future securities, tangible or intangible assets, as well as funds on the terms, specified therein or the obligation to make payments in result of a credit event.

Thus, the basis of the classification is the broadest concept of "derivative financial instruments", which, in turn, are divided into derivative securities and term contracts (derivatives) (Figure 1). In this case, hybrid securities and securitization instruments, which are presented in Figure 1 as structured securities and secured derivative securities, should be classified as derivative securities. The main features of derivatives securities are the following:

1) their release is made on the basis of emission;

2) they certify the right to other securities (hybrid) or the right to receive income generating their provision (securitization instruments);

3) provide for the regular receipt of fixed income and/ or income from changes in their market value (income in the form of exchange differences).

As a rule, structured securities are issued in the course of classical assets securitization, when there is a real sale of the last to a special financial intermediary that issues them. Such securities in practice receive high ratings, as they are separated from the activities of their primary owner (usually a commercial bank) and have their own security, generating regular income.

Direct distribution structures are characterized by a higher level of risk, as the core of these instruments is quite simple: the primary owner receives payments on loans from borrowers and redirects them to a special financial intermediary, which at the expense of these funds makes regular payments on securities issued by the financial intermediary on the basis of direct distribution. Increase the reliability of direct distribution structures by creating additional reserves, dividing emissions into tranches with different levels of credit risk and yield, and by incorporating credit derivatives into these structures.

Payment management structures from the very beginning are characterized by a lower level of risk compared to direct distribution structures. The essence of the payment management structures is that not all funds received by a special financial intermediary from the previous owner of securitized assets are immediately paid out on issued securities but only a portion of income or nominal value is paid, and the other part of the funds special financial intermediary invests in the most reliable assets (for example, government bonds) and receives additional income; so, in case of defaults on assets acquired through the securitization, a special financial intermediary always has a reserve to cover such losses.

Falseness of the risk assessment, both through direct distribution structures and payments management structures, on the eve of the financial crisis of 20072009 , consisted in the full confidence of leading rating agencies that provided such structures with ratings higher than those of initial owners of securitized assets and even ratings of the country of their formation. The maladdiction of the assessments was that the primary owners of assets (loan portfolios), from the outset with the aim of selling these assets, issued loans knowingly to insolvent borrowers on the mortgage purchased in real estate loans. While prices on real estate markets grew, loan collateral allowed it to be fully repaid. Portfolios of loans were sold by special financial intermediaries, whose founders were the banks themselves - the owners of these loan portfolios, so there were no special comments on the quality of these assets in special financial intermediaries. High ratings for debt securities of special financial intermediaries, secured by loan repayments, were assigned by separating these loan portfolios from the risks of the activities of their primary owners - banks and, since the special financial intermediary did not engage in activities other than the issuance of secured debt obligations, the risks of its activities were equal to zero. In addition, discussed securities due to high ratings were willingly insured by credit derivatives, which, in turn, increased their ratings even higher. The crisis began with falling prices in real estate markets, which significantly reduced the cost of collateral for loans, non-creditworthy borrowers stopped to make payments on loans, which in turn led to a significant fall in the ratings of secured securities, which was, in essence, regarded as a default and demanded payments on credit derivatives. The banks, founders of special financial intermediaries, were forced to recognize and cover the losses of these separated companies by court decisions, which led to financial problems in banks. 


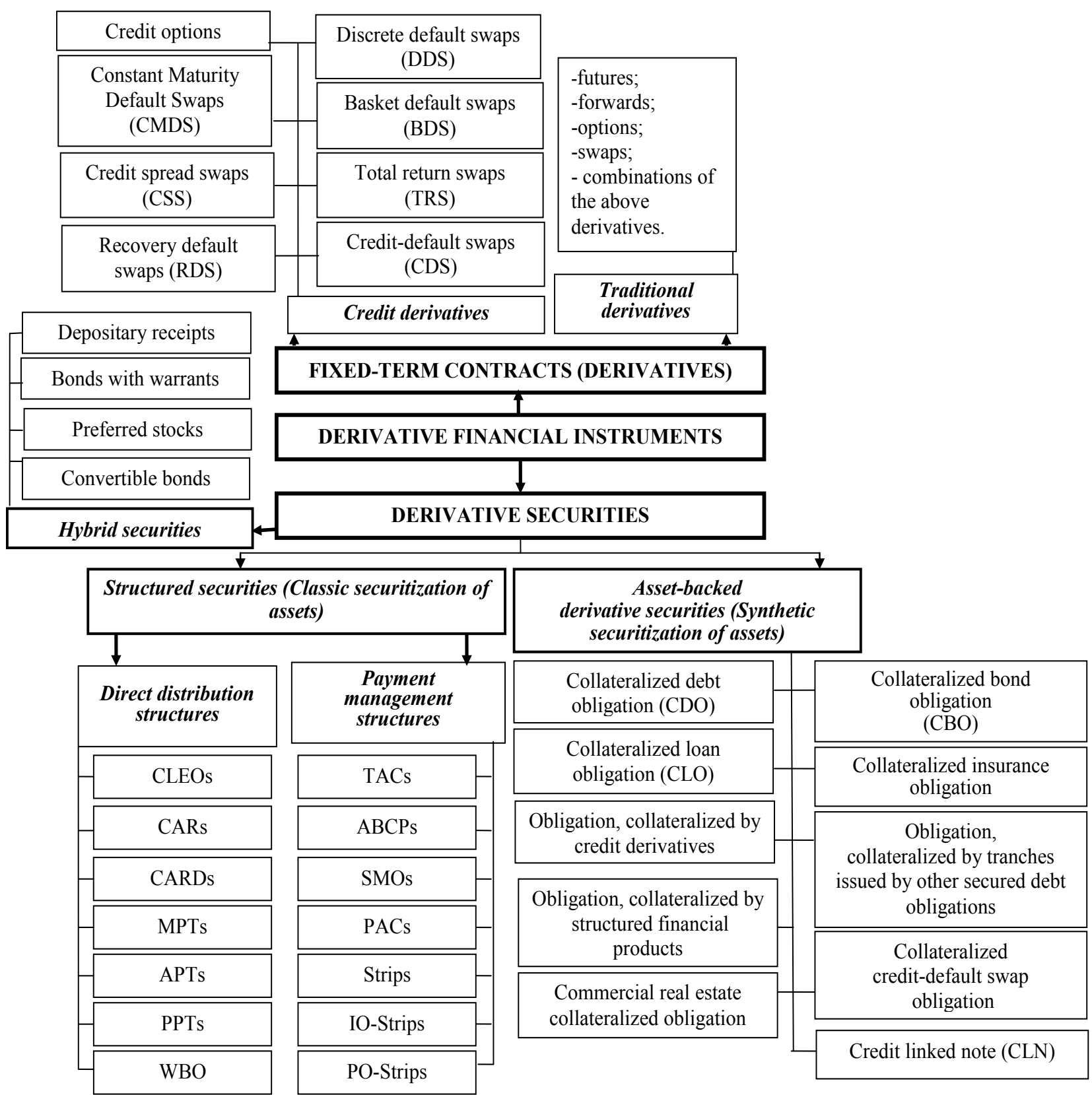

Figure 1. Classification of Derivative Financial Instruments

Secured derivative securities (synthetic securitization instruments) are characterized by the fact that their issuer is directly the owner of the loan portfolio, but in the prospectus of their issue, it is indicated that the payment for these securities, secured by the proceeds, is generated by the loan portfolio. Thus, unlike conventional bonds, synthetic securitization instruments have their own security and, in case of default, the issuer will be repaid precisely at the expense of its specific assets. However, the credit rating of synthetic securitization instruments will depend on the issuer's credit rating. The increase in the rating of synthetic securitization instruments is carried out mainly by embedding into their structure of credit derivatives.
Some scholars also consider the credit derivatives themselves as synthetic securitization instruments since the main purpose is the transfer of credit risk. However, based on the research, credit derivatives should be classified in a separate group. In particular, a credit derivative, for example, a credit default swap does not have any evidence of security until it starts trading on the market as a separate instrument; in this case, it has a credit rating and can generate income as a result of changing its market price. If, however, the credit derivative is not traded on the market, then it represents a term contract, the terms of which protect the buyer of protection against credit risks by structured securities. 
Hybrid securities are characterized by the fact that they combine the properties of the two securities simultaneously, they have a longer history of functioning in comparison with instruments of assets securitization and credit derivatives. Most types of hybrid securities are characterized by a change in the status of their owner during the term of the treatment or at its completion. Such securities do not have hidden risks in the form of artificially inflated ratings and depend exclusively on the rating of their issuer.

As for other traditional derivatives (futures, options, swaps), their affiliation with securities or financial instruments will be determined depending on whether they are traded on the market and what the purpose have: if to get the income from the fluctuation of their value in the market - then they should be classified as derivative securities, but if the main objective is to minimize risk, and not by issuing, then it should be attributed to fixed-term contracts (derivatives).

Detailing of certain types of structured securities, derivative securities, and credit derivatives, presented in Fig. 1, was implemented earlier and reflected in the paper "Instruments of asset securitization and their use prospects in Ukraine” (Novak, 2012).

\section{Conclusions}

The conducted research has made it possible to streamline the conceptual apparatus in relation to derivative financial instruments and group their separate types according to certain classification grounds. The classification is based on the broadest concept of "derivative financial instruments", which is understood as financial contracts or financial instruments derived from (based on) other financial instruments that are called base instruments, and may be assets (for example, goods, mortgage, real estate, bonds, loans), indices (interest rates, exchange rates, stock indices, consumer price indices) or other conditions, in particular, credit derivatives come from loans, bonds or other forms of lending. In the developed classification of derivative financial instruments, based on terminology research, it is proposed to distinguish "derivatives" and "derivative securities", and substantiated their significant differences. It is established that derivatives are standard documents that certify the right and/or obligation to purchase or sell securities in the future, tangible or intangible assets, as well as funds, or make payments on terms and conditions, specified by it. In some cases, derivatives may acquire features of derivative securities, in particular, when issued through emission and freely traded in markets and bring income (loss) to their owner as a result of changes in their market value.

In order to regulate emissions and investments in derivative financial instruments, financial institutions (primarily those, involving public funds: commercial banks, non-state pension funds, and life insurance companies) need to analyse selected groups of derivative financial instruments for hidden risks that, previously, were not taken into account during evaluation. In particular, for all instruments of assets securitization and credit derivatives, the risk of changes in the price of collateral for credits was not taken into account, which, in fact, led to the financial crisis of 2007-2009 years. Further research should be focused on identifying and detailing hidden risks in the context of each instrument, as well as developing a methodology for assessing these risks.

\section{References:}

Bär, Hans Peter (2006). Sekyuritizatsiya aktivov: sekyuritizatsiya finansovykh aktivov - innovatsionnaya tekhnika finansirovaniya bankov [Asset securitization: securitization of financial assets - innovative technique for financing banks]. Moskva: Volters Kluver. (in Russian)

Burenin, A. N. (1998). Rynok tsennykh bumag i proizvodnykh finansovykh instrumentov: uchebnoe posobie [Securities and derivatives financial instrument market]. Moskva: 1 Federativnaya Knigotorgovaya Kompaniya. (in Russian)

Busel, T. V. (2005). Velykyj tlumachnyj slovnyk suchasnoji ukrajinsjkoji movy (z dod. i dopov.) [Great explanatory dictionary of modern Ukrainian language]. Kyiv, Irpinj: VTF "Perun”. (in Ukrainian)

Desjardins Jeff (2017). All of the World's Money and Markets in One Visualization. Retrieved from: http://money.visualcapitalist.com/worlds-money-markets-one-visualization-2017/

Dziubliuk, O. V. (2009). Pro dejaki aspekty vykorystannja kredytnykh deryvatyviv u bankivsjkomu ryzykmenedzhmenti [About some aspects of use credit derivatives in bank risk-management]. Bulletin of the Khmelnytsky National University, 2, 21-23.

Fabozzi, F. J. (2007). Rynok obligatsiy: Analiz i strategii [Bond Markets : Analysis and Strategies]. Moskva: Alpina Biznes Buks. (in Russian)

Feldman, A. B. (2003). Proizvodnye finansovye i tovarnye instrumenty [Derivative financial and commodity instruments]. Moskva: Finansy i statistika. (in Russian)

Kuznetsova, L. V., Abramova, T. Ju. (2016). Osoblyvosti vykorystannja kredytnykh deryvatyviv u dijaljnosti bankiv [Features of use of credit derivatives in the activities of banks]. Scientific Herald of Kherson State University, 18, $168-171$.

Kvaktun, O. O. (2014). Osoblyvosti uchasti Ukrajiny na svitovomu rynku deryvatyviv [Features of Ukraine's participation in the world market of derivatives]. Economic space, 83, 16-24. 
Loginov, E. L., Loginova, V. E. (2012). Derivativy v rossiyskoy ekonomike: strategicheskie trendy upravleniya asimmetrichnostyu raspredelennykh rynkov [Derivatives in the economy of Russia: strategic trends of managing the asymmetricity of distributed markets]. Finance and credit, 30(510), 26-33.

Makshanova, T. V., Kovalenko, O. G. (2013). Proizvodnye tsennye bumagi i finansovye instrumenty: sushchnost i vozmozhnosti primeneniya [Derivative securities and financial instruments: essence and application possibilities]. Vector Science TSU, 3, 348-352.

Moshenskyi, S. Z. (2018). Khaos i sinergiya: Rynok tsennykh bumag postindustrialnoy epokhi [Chaos and synergy. The securities market of the postindustrial era]. Kyiv: VB «Vipol». (in Ukrainian)

Nacionaljnyj bank Ukrajiny (2018). Ghlosarij bankivsjkoji terminologhiji [Glossary of banking terminology]. Retrieved from: https://bank.gov.ua/control/uk/publish/article?art_id=123545\&cat_id=123512

Norman, P. (2013). Upravlyaya riskami. Kliring s uchastiem tsentralnykh kontragentov na globalnykh finansovykh rynkakh [Risk Controllers: Central Counterparty Clearing in Globalised Financial Markets]. Moskva: Mann, Ivanov i Ferber. (in Russian)

Novak, O. S. (2012). Instrumenty sekjurytyzaciji aktyviv ta perspektyvy jikh vykorystannja v Ukrajini [Instruments of asset securitization and prospects for their use in Ukraine]. Economic forum, 2, 487-494.

Poodwaddle world clock (2018). Gross world product. Retrieved from: http://www.poodwaddle.com/ worldclock/soc1/

Prymostka, L. (2001). Finansovi deryvatyvy: analitychni ta oblikovi aspekty: monoghrafija [Financial derivatives: analytical and accounting aspects: monograph]. Kyiv: KNEU. (in Ukrainian)

Rykova, L. M., Viktorovich, P. V. (2009). Risk-orientirovannyy bankovskiy nadzor na rynke derivativov [Riskoriented banking surveillance on the derivatives market]. Vjesnik BDEU, 3(74), 62-68.

Sheludjko, V., Virchenko, V. (2014). Suchasni tendenciji rozvytku svitovogho rynku deryvatyviv [Modern trends of development of world derivatives market]. Bulletin of the Kyiv National University named after Taras Shevchenko, 10(163), 81-87.

Sinkey, J. (2007). Finansovyy menedzhment v kommercheskom banke i v industrii finansovykh uslug [Financial management in a commercial bank and in the financial services industry]. Moskva: Alpina Biznes Buks. (in Russian) Tony Rice, Brian Coyle (1995). Finansovye investitsii i risk [Financial investment and risk]. Kyiv: Torgovoizdatelskoe byuro BHV. (in Ukrainian)

Verkhovna rada Ukrajiny (2012). Mizhnarodnyj standart bukhghaltersjkogho obliku 32 (msbo 32) Finansovi instrumenty: podannja [International Accounting Standard 32 (IAS 32) Financial Instruments: Presentation]. Retrieved from: http://zakon.rada.gov.ua/laws/show/929_029\#n27

Verkhovna rada Ukrajiny (2012). Mizhnarodnyj standart finansovoji zvitnosti 9 (msfz 9) finansovi instrumenty [International Financial Reporting Standards 9 (IFRS 9) Financial instruments]. Retrieved from: http://zakon.rada.gov.ua/laws/show/929_016

Vidomosti Verkhovnoji Rady Ukrajiny (2006). Zakon Ukrajiny "Pro cinni papery ta fondovyj rynok" [Law of Ukraine "On Securities and Stock Market"]. Retrieved from: http://zakon2.rada.gov.ua/laws/show/3480-15

Vidomosti Verkhovnoji Rady Ukrajiny (2010). Podatkovyj kodeks Ukrajiny [Tax Code of Ukraine]. Retrieved from: http://zakon2.rada.gov.ua/laws/show/2755-17/page2?text=\%E4\%E5\%F0\%E8\%E2\%E0\%F2\%E8\%E2

Jan Job de Vries Robbe, Paul Ali (2008). [Securitization and Law]. Moskva: Alpina Biznes Buks. (in Russian) 